\title{
Pertumbuhan Bibit Kakao (Theobroma cacao L.) pada Berbagai Jenis Klon dan Jenis Pupuk Kandang
}

\section{(Growth of Cocoa Seedlings [Theobroma cacao L.] on Various Types of Clones and Types of Manure)}

\author{
Leni Sri Widyastuti ${ }^{*}$, Yonathan Parapasan ${ }^{2}$, Made Same ${ }^{2}$ \\ 1 Program Studi Produksi dan Manajemen Industri Perkebunan Jurusan Budidaya Tanaman \\ Perkebunan Politeknik Negeri Lampung, Jl. Soekarno-Hatta No. 10 Rajabasa, Bandar Lampung, \\ 35144, Telp.:(0721) 703995, Fax.: (0721) 787309, ${ }^{2}$ Jurusan Budidaya Tanaman Perkebunan \\ Politeknik Negeri Lampung, Jl. Soekarno-Hatta No. 10 Rajabasa, Bandar Lampung, 35144, \\ Telp.:(0721) 703995, Fax.: (0721) 787309
}

E-mail: leni.sri10111@gmail.com

\section{ARTICLE INFO}

Article history

Submitted: March 30, 2020

Accepted: October 4, 2021

Published: October 26, 2021

Keywords:

growth factor, organic fertilizer, planting media, vegetatife growth

\begin{abstract}
Several factors affect the production of cocoa (Theobroma cacao L.), one of which is the quality of seedlings. The quality of seedlings is affected by the type of clones and the composition of the planting media. This study aims to obtain the influence of clone types and types of manure and the interaction between clone types and types of manure on the growth of cocoa seedlings. The study was conducted in the teaching farm and the laboratory of the Politeknik Negeri Lampung from January 2017 to June 2017. The method used was a Randomized Block Design (RBD) factorial pattern consisting of two factors. The first factor is the type of clone consisting of three levels, namely $K_{1}=$ TSH clone 858, $K_{2}=I C S 60$, and $K_{3}=$ TSH 908. The second factor consisting of four levels namely $P_{0}=$ control, $P_{1}=$ chicken manure, $P_{2}=$ cow manure, and $P_{3}=$ goat manure. The results showed that the use of TSH 858, ICS 60, and TSH 908 clones had the same effect on all observed variables. However, the use of manure has a significant effect on each variable, but the amount of leaf chlorophyll is relatively the same between clone types and types of manure. There are interactions between clone types and types of manure.
\end{abstract}

Copyright (c) 2021 Author(s). This work is licensed under a Creative Commons AttributionShareAlike 4.0 International License.

\section{PENDAHULUAN}

Kakao (Theobroma cacao L.) merupakan salah satu komoditas perkebunan yang memiliki peranan yang cukup penting dalam mewujudkan program pembangunan pertanian, khususnya dalam hal penyediaan lapangan kerja, pendorong pengembangan wilayah, peningkatan kesejahteraan petani, dan peningkatan pendapatan atau devisa negara. Dalam perkembangannya, produktivitas kakao Indonesia sampai saat ini masih rendah di bawah potensinya, yaitu sekitar $2.000 \mathrm{~kg} \cdot \mathrm{ha}^{-1}{ }^{-1}$ tahun $^{-1}$. Pada 2019, produktivitas perkebunan rakyat sebesar 731 kg.ha. ${ }^{-1}$.tahun ${ }^{-1}$, Perkebunan Besar Negara sebesar 761 kg.ha. ${ }^{-1}$.tahun ${ }^{-1}$, dan PBS sebesar 612 kg.ha. ${ }^{-1}$.tahun ${ }^{-1}$ (Direktorat Jenderal Perkebunan Indonesia, 2019). Perkebunan Rakyat menyumbang $98 \%$ produksi kakao di Indonesia, yang menunjukkan bahwa saat ini produksi kakao Indonesia bergantung pada Perkebunan Rakyat. 
Salah satu penyebab rendahnya produktivitas kakao di Perkebunan Rakyat adalah belum menggunakan bibit dari klon atau varietas unggul atau masih menggunakan bibit asalan (Direktorat Jenderal Perkebunan Indonesia, 2015). Di samping itu, faktor lain yang dapat menyebabkan rendahnya kualitas bibit adalah penggunaan bahan media tanam yang belum optimal. Hasil penlitian terdahulu menunjukkan bahwa pertumbuhan bibit kakao dapat dipacu dengan penambahan pupuk kandang dan pupuk anorganik (Desiana et al., 2013; Sitompul at al., 2014). Mencermati pentingnya produksi bibit tanaman kakao unggul dan berkualitas, maka perlu dilakukan studi lebih lanjut tentang respons beberapa klon bibit kakao yang diberi pupuk kandang.

Produksi dan produktivitas tanaman kakao sangat ditentukan oleh faktor genetik tanaman. Klon kakao unggul memiliki potensi hasil panen yang tinggi, tahan terhadap serangan hama dan penyakit, responsif terhadap pemupukan, dan karakter unggul lainnya. Media tanam merupakan komponen utama yang dapat mempengaruhi kualitas bibit yang dihasilkan. Secara umum, media tanam yang baik harus dapat menjaga kelembapan optimal di daerah sekitar perakaran, menyediakan oksigen yang cukup, dan dapat menyediakan unsur hara yang cukup bagi pertumbuhan bibit. Ketersediaan unsur hara, air dan oksigen pada media tanam dapat ditingkatkan dengan menggunakan pupuk organik. Pupuk organik terdiri dari beberapa jenis dan salah satunya adalah pupuk kandang, baik dalam bentuk padat atau cair yang dapat mensuplai bahan organik, menyediakan unsur hara makro dan mikro, memperbaiki sifat fisik, kimia, dan biologi tanah (Sari, 2015).

Untuk mendapatkan bibit kakao berkualitas, selain menggunakan klon unggul juga perlu dipadukan dengan penggunaan beberapa jenis pupuk kandang sebagai media tanam sehingga dapat menghasilkan pertumbuhan dan performa bibit yang optimal. Klon unggul diharapkan dapat menghasilkan bibit yang unggul pada berbagai jenis pupuk kandang sebagai sumber nutrisi, air dan keadaan media tanam yang gembur. Penelitian ini bertujuan untuk mendapatkan jenis klon dan jenis pupuk kandang terbaik, serta mendapatkan interaksi antara keduanya pada pertumbuhan bibit kakao.

\section{METODE PENELITIAN}

Penelitian dilaksanakan di lahan praktik Jurusan Tanaman Perkebunan dan Laboratorium Analisis Politeknik Negeri Lampung, dilaksanakan mulai Januari 2017 sampai dengan Juni 2017. Alat dan bahan yang digunakan adalah: alat tulis, gunting, penggaris, kamera, jangka sorong, pisau karter, koret, SPAD-502, polibeg, bambu, kertas label, benih kakao klon TSH 858, ICS 60, Klon TSH 908, pupuk kandang ayam, pupuk kandang sapi, dan pupuk kandang kambing.

Rancangan yang digunakan adalah rancangan acak kelompok (RAK) pola Faktorial, yang terdiri atas dua faktor. Faktor petama adalah jenis klon yang terdiri atas tiga jenis, yaitu $\mathrm{K}_{1}=\mathrm{Klon} \mathrm{TSH} 858$, $\mathrm{K}_{2}=$ ICS 60, dan $\mathrm{K}_{3}=$ TSH 908. Faktor kedua adalah jenis pupuk kandang yang terdiri atas empat macam yaitu $\mathrm{P}_{0}=$ Kontrol, $\mathrm{P}_{1}=$ Pupuk kandang ayam, $\mathrm{P}_{2}=$ Pupuk kandang sapi, dan $\mathrm{P}_{3}=$ Pupuk kandang kambing. Penelitian diulang tiga kali dengan 12 kombinasi perlakuan sehingga terdapat 36 satuan percobaan.

Tahapan pelaksanaan penelitian meliputi persiapan lahan persemaian, persiapan benih, persiapan media tanam, dan pemindahan bibit ke polibeg. Bahan yang digunakan dalam penelitian ini yaitu benih kakao yang diperoleh dari PTPN VII Unit Way Berulu, Pesawaran, Lampung. Bahan untuk media tanam meliputi tanah lapisan atas (top soil) dan pupuk kandang (sapi, ayam, dan kambing) dengan perbandingan 1:1 (v:v) yang diperoleh dari kandang peternakan Politeknik Negeri Lampung. Persemaian benih kakao dilakukan menggunakan media pasir dan disiram setiap pagi dan 
sore sampai bibit siap pindah tanam, persiapan media tanam pada polibeg dengan mencampurkan tanah dan pupuk kandang yang kemudian dimasukkan ke dalam polibeg. Pemindahan dan penanaman bibit dari persemaian ke polibeg pada lahan yang telah diberi naungan yang terbuat dari paranet. Bibit kakao dalam polibeg disiram menggunakan gembor setiap pagi dan sore yang kemudian dilakukan pengamatan.

Pengamatan dilakukan pada akhir penelitian saat bibit berumur 20 minggu setelah tanam (MST) yang meliputi: tinggi bibit, diameter batang, jumlah daun, panjang akar, bobot kering akar, luas daun, indeks kehijauan daun, dan bobot kering brangkasan. Data dianalisis dengan sidik ragam pada taraf nyata 5\% dan dilanjutkan dengan uji lanjut beda nyata terkecil (BNT).

\section{HASIL DAN PEMBAHASAN}

\section{Tinggi Bibit Kakao}

Hasil sidik ragam tinggi bibit kakao (Tabel 1) menunjukkan bahwa penggunaan beberapa jenis klon tidak berpengaruh pada tinggi bibit kakao, sedangkan perlakuan jenis pupuk kandang memberikan pengaruh. Namun, interaksi antara jenis klon dengan jenis pupuk kandang tidak berpengaruh pada tinggi bibit kakao.

Tabel 1. Pengaruh jenis klon dan jenis pupuk kandang pada tinggi bibit kakao (cm)

\begin{tabular}{lc}
\hline \multicolumn{1}{c}{ Perlakuan } & Rerata \\
\hline Jenis klon & \\
TSH 858 & 44,00 \\
ICS 60 & 44,47 \\
TSH 908 & 43,96 \\
\hline Jenis pupuk kandang & $43,42 \mathrm{a}$ \\
Tanah tanpa pupuk kandang & $45,31 \mathrm{~b}$ \\
Pupuk kandang ayam + tanah & $44,21 \mathrm{a}$ \\
Pupuk kandang sapi + tanah & $43,63 \mathrm{a}$ \\
Pupuk kandang kambing + tanah & 0,8 \\
\hline BNT 5\% & $(-)$ \\
\hline Interaksi &
\end{tabular}

Tinggi bibit kakao pada ketiga jenis klon relatif sama (Tabel 1). Hal ini menunjukkan bahwa klon TSH 858, klon ICS 60, dan klon TSH 908 relatif memberikan tampilan pertumbuhan fenotipik yang sama, sehingga ketiga klon tersebut dapat dikategorikan memiliki keunggulan yang relatif sama sebagai sumber bibit. Sebaliknya, tinggi bibit kakao pada beberapa jenis pupuk kandang berbedabeda, tetapi yang tertinggi terdapat pada perlakuan pupuk kandang ayam yang berbeda sangat nyata dengan tinggi bibit pada perlakuan pupuk kandang lain. Hal ini diduga terjadi karena ketersediaan unsur hara pada pupuk kandang ayam lebih tinggi dibandingkan pupuk kandang lainnya. Jumini et al. (2011) menyatakan bahwa kandungan N, P, dan K pada setiap pupuk organik mempunyai peranan dalam merangsang pertumbuhan vegetatif serta memacu pertumbuhan jaringan terutama pada tinggi tanaman, jumlah anakan dan daun. Pertumbuhan suatu tanaman tidak akan maksimal jika kandungan unsur hara yang tersedia kurang dari yang dikehendaki (Syafruddin et al., 2012). Selanjutnya Jumini et al. (2011) menyatakan bahwa jika suatu tanaman kekurangan kandungan unsur hara pupuk, laju 
pertumbuhan tanaman tersebut akan lambat dan produksinya tidak optimal. Kandungan $\mathrm{N}$ yang tercukupi dapat merangsang pertumbuhan secara keseluruhan bagian tanaman khususnya batang, cabang, dan daun tanaman (Hasiholan et al, 2017). Secara umum, pemberian pupuk kandang dapat meningkatkan kesuburan tanah, mempertinggi kadar humus, memperbaiki struktur tanah dan mendorong aktivitas mikroorganisme tanah dengan meningkatnya ketersediaan dan serapan unsur hara $\mathrm{N}, \mathrm{P}$, dan $\mathrm{K}$ dari pupuk kandang dapat memicu pertumbuhan tanaman.

\section{Diameter Batang Bibit Kakao}

Tabel 2 menunjukkan bahwa diameter batang bibit kakao pada ketiga jenis klon yang digunakan relatif tidak berbeda, akan tetapi diameter batang bibit kakao pada berbagai jenis pupuk kandang memberikan pengaruh pada pertumbuhan diameter batang bibit kakao.

Tabel 2. Pengaruh jenis klon dan jenis pupuk kandang pada diameter batang bibit kakao (mm)

\begin{tabular}{lc}
\hline \multicolumn{1}{c}{ Perlakuan } & Rerata \\
\hline Jenis klon & 0,65 \\
TSH 858 & 0,64 \\
ICS 60 & 0,64 \\
TSH 908 & $0,61 \mathrm{a}$ \\
\hline Jenis pupuk kandang & $0,68 \mathrm{~b}$ \\
Tanah tanpa pupuk kandang & $0,65 \mathrm{~b}$ \\
Pupuk kandang ayam + tanah & $0,63 \mathrm{~b}$ \\
Pupuk kandang sapi + tanah & 0,025 \\
Pupuk kandang kambing + tanah & $(-)$ \\
\hline BNT 5\% &
\end{tabular}

Tabel 2 menunjukkan bahwa diameter batang bibit kakao akibat pemberian pupuk kandang mempunyai nilai yang tidak jauh berbeda, perlakuan kontrol mempunyai nilai terendah $(0,61 \mathrm{~mm})$ sedangkan semua jenis pupuk kandang mempunyai nilai yang berbeda. Hal ini diduga tersedianya unsur hara dalam jumlah yang cukup melalui pemberian pupuk organik menyebabkan kegiatan metabolisme dari tanaman meningkat. Nugrahini (2013) menyatakan bahwa batang merupakan daerah akumulasi pertumbuhan tanaman khususnya tanaman muda, dengan adanya unsur hara dapat mendorong laju fotosintesis dalam menghasilkan fotosintat, sehingga membantu dalam pembentukan lilit batang. Menurut Hartatik et al. (2011), unsur K sangat berperan dalam meningkatkan diameter batang tanaman, khususnya dalam peranannya sebagai jaringan yang menghubungkan antara akar dan daun, kekurangan unsur $\mathrm{K}$ dapat menghambat proses pembesaran lingkar batang.

\section{Jumlah Daun Bibit Kakao}

Hasil sidik ragam jumlah daun bibit kakao (Tabel 3) menunjukkan bahwa perlakuan beberapa jenis klon tidak berpengaruh pada jumlah daun. Perlakuan beberapa jenis pupuk kandang memberikan pengaruh yang nyata, sedangkan interaksi antara jenis klon dan jenis pupuk kandang tidak berpengaruh pada jumlah daun. 
Tabel 3. Pengaruh jenis klon dan jenis pupuk kandang pada jumlah daun bibit kakao (helai)

\begin{tabular}{lc}
\hline \multicolumn{1}{c}{ Perlakuan } & Rerata \\
\hline Jenis klon & \\
TSH 858 & 11,04 \\
ICS 60 & 11,41 \\
TSH 908 & 10,71 \\
\hline Jenis pupuk kandang & $10,11 \mathrm{a}$ \\
Tanah tanpa pupuk kandang & $11,11 \mathrm{~b}$ \\
Pupuk kandang ayam + tanah & $10,66 \mathrm{~b}$ \\
Pupuk kandang sapi + tanah & $10,55 \mathrm{~b}$ \\
Pupuk kandang kambing + tanah & 0,5 \\
\hline BNT 5\% & $(-)$ \\
\hline Interaksi &
\end{tabular}

Tabel 3 menunjukkan bahwa ketiga jenis klon yang diteliti memiliki jumlah daun yang relatif sama, tetapi jumlah daun pada klon ICS 60 relatif lebih tinggi. Pada perlakuan jenis pupuk kandang, kontrol mempunyai jumlah daun terendah yakni 10,11 helai, sedangkan perlakuan jenis pupuk kandang lainnya mempunyai jumlah daun yang berbeda. Lebih tingginya jumlah daun pada perlakuan pupuk kandang, diduga terjadi karena ketersediaan $\mathrm{N}$ pada perlakuan pupuk kandang lebih tinggi dibandingkan dengan perlakuan klon. Seperti dikemukakan oleh Ulfa (2018), unsur hara yang paling berpengaruh terhadap pertumbuhan dan perkembangan daun adalah unsur N. Kadar unsur N yang banyak umumnya menghasilkan daun yang lebih banyak dan lebih besar. Menurut Adriansyah (2013), nitrogen merupakan komponen utama untuk pertumbuhan tanaman khususnya pertumbuhan vegetatif seperti pembentukan daun. Hal ini didukung dengan pernyataan Ulfa (2018), bahwa unsur hara yang paling berpengaruh terhadap pertumbuhan dan perkembangan daun adalah nitrogen.

\section{Panjang Akar Bibit Kakao}

Hasil sidik ragam panjang akar bibit kakao (Tabel 4) menunjukkan bahwa perlakuan beberapa jenis klon tidak berpengaruh pada panjang akar, perlakuan beberapa jenis pupuk kandang memberikan pengaruh yang nyata, sedangkan interaksi antara jenis klon dan jenis pupuk kandang tidak berpengaruh pada panjang akar. Tabel 4 menunjukkan bahwa perlakuan ketiga jenis klon memberikan pengaruh yang relatif sama pada variabel panjang akar tanaman kakao, perlakuan kontrol mempunyai nilai terendah $(26,67 \mathrm{~cm})$, sedangkan perlakuan semua jenis pupuk kandang mempunyai nilai relatif sama. Hal ini diduga pemberian pupuk kandang membantu dalam proses memperbaiki fisika dan biologi tanah, sehingga menjadi unsur hara yang tersedia bagi tanaman.

Bahan organik akan memperbaiki sifat biologi tanah sehingga tercipta lingkungan yang lebih baik bagi perakaran tanaman sehingga akar dapat menyerap unsur hara yang lebih banyak (Pangaribuan \& Pujisiswanto, 2008). Listiana et al. (2010) menyatakan bahwa bahan organik menyumbangkan total ruang pori lebih banyak dan kapasitas memegang air yang lebih tinggi pada zona perakaran dan menghasilkan perakaran yang lebih kuat. Akar-akar yang halus ini merupakan bagian akar yang paling aktif melaksanakan absorbsi hara dan air. Semakin banyak akar halus yang terbentuk, jumlah unsur hara dan air yang diabsorbsi oleh tanaman semakin besar. Sari (2009) menyatakan bahwa media tanam yang baik untuk pertumbuhan bibit kakao adalah media yang cukup 
porus sehingga akar mudah menembusnya dan berkembang dengan baik. Pupuk kandang berperan dalam memperbaiki sifat fisik tanah, yaitu memiliki porositas yang cukup tinggi namun bisa diatur kepadatannya sehingga media tanam menjadi gembur dan dapat menyimpan zat hara seperti halnya tanah.

Tabel 4. Pengaruh jenis klon dan jenis pupuk kandang pada panjang akar bibit kakao (cm)

\begin{tabular}{lc}
\hline \multicolumn{1}{c}{ Perlakuan } & Rerata \\
\hline Jenis klon & 27,33 \\
TSH 858 & 27,69 \\
ICS 60 & 27,52 \\
TSH 908 & \\
\hline Jenis pupuk kandang & $26,67 \mathrm{a}$ \\
Tanah tanpa pupuk kandang & $28,50 \mathrm{~b}$ \\
Pupuk kandang ayam + tanah & $27,93 \mathrm{~b}$ \\
Pupuk kandang sapi + tanah & $26,94 \mathrm{~b}$ \\
Pupuk kandang kambing + tanah & 0,7 \\
\hline BNT 5\% & $(-)$ \\
\hline Interaksi &
\end{tabular}

\section{Bobot Kering Akar Bibit Kakao}

Hasil sidik ragam bobot akar bibit kakao (Tabel 5) menunjukkan bahwa perlakuan beberapa jenis pupuk kandang memberikan pengaruh yang nyata, perlakuan beberapa jenis klon tidak berpengaruh nyata pada bobot akar bibit kakao, sedangkan interaksi antara jenis klon dan jenis pupuk kandang tidak berpengaruh pada panjang akar.

Tabel 5. Pengaruh berbagai jenis klon dan jenis pupuk kandang pada bobot kering akar bibit kakao (g)

\begin{tabular}{lc}
\hline \multicolumn{1}{c}{ Perlakuan } & Rerata \\
\hline Jenis klon & 1,61 \\
TSH 858 & 1,62 \\
ICS 60 & 1,58 \\
TSH 908 & $1,50 \mathrm{a}$ \\
\hline Jenis pupuk kandang & $1,74 \mathrm{~b}$ \\
Tanah tanpa pupuk kandang & $1,63 \mathrm{~b}$ \\
Pupuk kandang ayam + tanah & $1,52 \mathrm{a}$ \\
Pupuk kandang sapi + tanah & 0,065 \\
Pupuk kandang kambing + tanah & $(-)$ \\
\hline BNT 5\% &
\end{tabular}

Tabel 5 menunjukkan bahwa perlakuan ketiga jenis klon memberikan pengaruh yang tidak jauh berbeda pada variabel pengamatan panjang akar tanaman kakao. Perlakuan kontrol dan pupuk kandang kambing mempunyai nilai bobot yang telatif sama, sedangkan pupuk kandang ayam mempunyai bobot kering akar tidak jauh berbeda dengan perlakuan jenis pupuk kandang sapi. Hal ini 
diduga bahwa kondisi media yang remah, ketersediaan unsur hara $\mathrm{N}, \mathrm{P}$, dan $\mathrm{K}$ yang memadai sehingga berpengaruh pada penambahan bobot akar bibit kakao. Harjanti (2014) menyatakan bahwa unsur hara makro seperti N, P, K, dan unsur hara mikro merupakan unsur hara utama bagi pertumbuhan tanaman. Apabila tanaman kekurangan unsur hara tersebut maka pertumbuhan akar lambat. Berat kering mencerminkan status nutrisi tanaman karena berat kering tersebut tergantung pada jumlah sel, ukuran sel, atau kualitas sel penyusun tanaman, hal ini tergantung pada ketersediaan unsur hara (Triastuti, 2016). Jumlah air dan hara yang diabsorbsi oleh tanaman ditentukan oleh volume tanah yang bersentuhan (kontak) dengan akar. Volume tanah yang bersentuhan dengan akar tergantung jumlah akar cabang dan jarak sampai sejauh mana akar berkembang baik ke arah vertikal maupun ke arah horizontal.

\section{Bobot Kering Brangkasan Bibit Kakao}

Hasil sidik ragam bobot kering brangkasan bibit kakao (Tabel 8) menunjukkan bahwa perlakuan beberapa jenis klon berpengaruh pada bobot kering brangkasan bibit kakao, perlakuan beberapa jenis pupuk kandang memberikan pengaruh yang nyata, sedangkan interaksi antara jenis klon dan jenis pupuk kandang tidak berpengaruh pada panjang akar.

Tabel 6. Pengaruh berbagai jenis klon dan jenis pupuk kandang pada bobot kering brangkasan bibit kakao $(\mathrm{g})$

\begin{tabular}{lc}
\hline \multicolumn{1}{c}{ Perlakuan } & Rerata \\
\hline Jenis klon & \\
TSH 858 & 3,16 \\
ICS 60 & 3,22 \\
TSH 908 & 3,11 \\
\hline Jenis pupuk kandang & $2,86 \mathrm{a}$ \\
Tanah tanpa pupuk kandang & $3,44 \mathrm{~b}$ \\
Pupuk kandang ayam + tanah & $3,26 \mathrm{~b}$ \\
Pupuk kandang sapi + tanah & $3,09 \mathrm{~b}$ \\
$\quad$ Pupuk kandang kambing + tanah & 0,18 \\
\hline BNT 5\% & $(-)$ \\
\hline Interaksi &
\end{tabular}

Berdasarkan Tabel 6, perlakuan ketiga jenis klon memberikan pengaruh yang relatif sama pada variabel bobot kering brangkasan tanaman kakao. Perlakuan kontrol mempunyai bobot kering brangkasan terendah $(2,86 \mathrm{~g})$ sedangkan semua perlakuan jenis pupuk kandang mempunyai bobot yang tidak jauh berbeda. Hal ini diduga pemberian pupuk organik selain dapat memperbaiki sifat fisik dan kimia tanah juga dapat mempertahankan bahan organik tanah, sehingga aktivitas biologis tanah dan transportasi unsur hara menjadi meningkat. Hal ini sesuai dengan Kuyik (2013) bahwa pupuk organik granul memiliki kandungan unsur hara makro dan mikro yang mampu memperbaiki struktur tanah, berperan dalampergerakan air dan partikel udara di dalam tanah mendorong aktivitas mikroorganisme yang menguntungkan dalam pertumbuhan akar. 


\section{Luas Daun Bibit Kakao}

Hasil sidik ragam luas daun bibit kakao (Tabel 7) menunjukkan bahwa perlakuan beberapa jenis klon berpengaruh nyata pada luas daun bibit kakao. Perlakuan beberapa jenis pupuk kandang memberikan pengaruh yang nyata, sedangkan interaksi antara jenis klon dan jenis pupuk kandang berpengaruh sangat nyata pada luas daun bibit kakao.

Tabel 7 menunjukkan bahwa luas daun tertinggi ditunjukkan dari interaksi antara perlakuan jenis klon TSH 908 dengan jenis pupuk kandang sapi sebesar $\left(77,3 \mathrm{~cm}^{2}\right)$ diikuti dengan perlakuan klon TSH 908 dengan pupuk kandang ayam $\left(77,2 \mathrm{~cm}^{2}\right)$, klon ICS 60 dengan pupuk kandang kambing $(76,6$ $\left.\mathrm{cm}^{2}\right)$, klon ICS 60 dengan pupuk kandang ayam $\left(75,3 \mathrm{~cm}^{2}\right)$, dan klon TSH 858 dengan pupuk kandang sapi $\left(75,3 \mathrm{~cm}^{2}\right)$. Hal ini diduga bahwa pemberian pupuk kandang dapat menigkatkan aktivitas fotosintesis cukup tinggi yang akan menghasilkan fotosintat yang mengakibatkan perkembangan pada jaringan meristem daun sehingga jumlah dan luas daun bertambah. Penambahan jumlah dan luas daun tersebut karena kebutuhan unsur hara $\mathrm{N}$ yang terpenuhi di dalam media tersebut. Jumini (2011) menyatakan bahwa ketersediaan unsur $\mathrm{N}$ akan mempengaruhi daun dalam bentuk dan jumlah. Tanaman yang dapat tumbuh dan berkembang dengan optimal jika tanaman mendapatkan dan mikro sehingga dapat memperbaiki keadaan sifat fisik tanah menjadi gembur dan aerasi menjadi lebih baik.

Tabel 7. Pengaruh interaksi berbagai jenis klon dan jenis pupuk kandang pada luas daun bibit kakao $\left(\mathrm{cm}^{2}\right)$

\begin{tabular}{lcccc}
\hline \multirow{2}{*}{ Jenis klon } & $\begin{array}{c}\text { Tanah tanpa } \\
\text { pupuk kandang }\end{array}$ & $\begin{array}{c}\text { pupuk kandang } \\
\text { ayam }+ \text { tanah }\end{array}$ & $\begin{array}{c}\text { pupuk kandang } \\
\text { sapi + tanah }\end{array}$ & $\begin{array}{c}\text { pupuk kandang } \\
\text { kambing + tanah }\end{array}$ \\
\hline TSH 858 & $71,4 \mathrm{a}$ & $71,8 \mathrm{a}$ & $75,3 \mathrm{~d}$ & $74,3 \mathrm{~b}$ \\
ICS 60 & $71,7 \mathrm{a}$ & $75,3 \mathrm{~d}$ & $74,7 \mathrm{c}$ & $76,6 \mathrm{~d}$ \\
TSH 908 & $71,0 \mathrm{a}$ & $77,2 \mathrm{~d}$ & $77,3 \mathrm{~d}$ & $71,0 \mathrm{a}$ \\
\hline BNT 5\% & \multicolumn{4}{c}{3,10} \\
\hline Keterangan: & $\begin{array}{l}\text { Nilai rata-rata yang diikuti huruf sama pada kolom yang sama menunjukkan tidak beda nyata } \\
\end{array}$ & menurut uji BNT pada taraf nyata 5\%
\end{tabular}

\section{Indeks Kehijauan Daun Bibit Kakao}

Hasil sidik ragam indeks kehijauan daun bibit kakao (Tabel 8) menunjukkan bahwa perlakuan beberapa jenis klon dan jenis pupuk kandang tidak berpengaruh pada jumlah klorofil daun bibit kakao, sedangkan interaksi antara jenis klon dan jenis pupuk kandang tidak berpengaruh pada indeks kehijauan daun. Hal ini diduga bahwa pemberian pupuk kandang tidak memiliki kemampuan mengikat air yang kuat yang mengakibatkan kurangnya klorofil yang terdapat pada daun. Kebutuhan air untuk proses fotosintesis tanaman dapat terpenuhi sehingga akan berpengaruh pada jumlah klorofil daun. Menurut Yusuf (2019), tanah yang aerasinya tidak baik memungkinkan udara akan sulit masuk ke dalam tanah sehingga tanah akan kekurangan oksigen dan berpengaruh kepada akar karena akar membutuhkan oksigen untuk melakukan respirasi. Kurangnya kandungan oksigen dalam tanah maka akan mengganggu proses respirasi yang dilakukan oleh akar. Terganggunya proses respirasi yang dilakukan oleh akar selanjutnya akan menghambat tanaman untuk dapat mensuplai energi yang penting untuk semua aktivitas sel termasuk pembelahan sel dan pertumbuhan tanaman. 
Tabel 8. Pengaruh jenis klon dan jenis pupuk kandang pada indeks kehijauan daun bibit kakao

\begin{tabular}{lc}
\hline \multicolumn{1}{c}{ Perlakuan } & Rerata \\
\hline Jenis klon & \\
TSH 858 & 33,26 \\
ICS 60 & 33,78 \\
TSH 908 & 32,11 \\
\hline Jenis pupuk kandang & 30,87 \\
Tanah tanpa pupuk kandang & 33,68 \\
Pupuk kandang ayam + tanah & 35,28 \\
Pupuk kandang sapi + tanah & 32,37 \\
Pupuk kandang kambing + tanah & \\
\hline
\end{tabular}

\section{KESIMPULAN}

Klon TSH 858, klon ICS 60, dan klon TSH 908 menghasilkan nilai yang hampir sama pada semua variabel pengamatan, sehingga ketiganya dapat dijadikan klon yang dapat dikembangkan lebih lanjut. Jenis pupuk kandang ayam mampu meningkatkan tinggi batang bibit kakao dan bobot kering akar bibit kakao. Penggunaan jenis pupuk kandang sapi mampu meningkatkan bobot kering akar bibit kakao, sedangkan jenis pupuk kandang kambing mampu meningkatkan diameter batang, jumlah daun, panjang akar, bobot kering brangkasan bibit kakao. Indeks kehijauan daun bibit kakao relatif sama pada semua jenis klon dan pada pemberian semua jenis pupuk kandang. Terdapat interaksi antara jenis klon bibit dan jenis pupuk kandang pada luas daun bibit kakao, dengan hasil terbaik dicapai dengan kombinasi klon ICS 60 dan pupuk kandang ayam + tanah, klon TSH 908 dan pupuk kandang ayam + tanah, klon TSH 858 dan pupuk kandang sapi + tanah, TSH 908 dan pupuk kandang sapi + tanah, serta klon ICS 60 dan pupuk kandang kambing + tanah.

\section{DAFTAR PUSTAKA}

Desiana, C., Banuwa, I. S., Evizal, R., \& Yusnaini, S. (2013). Pengaruh pupuk organik cair urin sapi dan limbah tahu terhadap pertumbuhan bibit kakao (Theobroma cacao L.). Jurnal Agrotek Tropika, 1(1), 113-119. http://dx.doi.org/10.23960/jat.v1i1.1927

Direktorat Jenderal Perkebunan. (2009). Statistik Perkebunan Indonesia 2018-2020: Kakao. Jakarta: Sekretariat Direktorat Jenderal Perkebunan, Direktorat Jenderal Perkebunan, Kementerian Pertanian.

Hartatik, W., Subiksa, I. G. M., \& Dariah, A. (2011). Sifat kimia dan fisik tanah gambut. Pada: Pengelolaan Lahan Gambut Berkelanjutan. Bogor: Balai Penelitian Tanah, 45.

Hasiholan, A., Armain, A., \& Yoseva, S. (2017). Pengaruh perbedaan dosis limbah cair bioetanol (vinasse) terfermentasi terhadap pertumbuhan bibit tanaman kakao (Theobroma cacao L.). Jurnal Online Mahasiswa Fakultas Pertanian Universitas Riau, 4(2), 1-15.

Jumini, J., Nurhayati, N, \& Murzani, M. (2011). Efek kombinasi dosis pupuk NPK dan cara pemupukan terhadap pertumbuhan dan hasil jagung manis. Jurnal Floratek, 6(2), 165-170.

Kuyik, A. R., Tumewu, P., Sumampow, D. M., \& Tulungen, E. G. (2013). Respons tanaman jagung manis (Zea mays saccharata L.) terhadap pemberian pupuk organik. Cocos, 2(4), 1-11. 
Listiana, N., Nawawi, N., \& Wardiyati, T. (2010). Pengaruh komposisi media tanam dan pupuk sp 36 terhadap pertumbuhan tanaman gladiol (Gladiolus Hybridus L). Buana Sains, 10(2), 147-152.

Nugrahini, T. (2013). Respon tanaman bawang merah (Allium ascolonicum L.) varietas tuk tuk terhadap pengaturan jarak tanam dan konsentrasi pupuk organik cair NASA. Ziraa'ah Majalah Ilmiah Pertanian, 36(1), 60-65.

Pangaribuan, D. H., \& Pujisiswanto, H. (2009). Pengaruh pupuk kompos jerami dan pemulsaan terhadap pertumbuhan dan hasil buah tomat. Prosiding SemNas TTG Agroindustri dan Diseminasi Hasil-hasil Penelitian Dosen Polinela 2009, 1-2 April 2009, 115-121.

Direktorat Jenderal Perkebunan. (2015). Statistik Perkebunan Indonesia. Jakarta (ID): Direktorat Jenderal Perkebunan.

Sari, M. P. (2009). Pengaruh Lama Perendaman dalam Urine Sapi dan Dosis Pupuk Kandang Sapi terhadap Pertumbuhan Setek Nilam (Pogostemon cablin Benth) (Doctoral dissertation, Universitas Sebelas Maret).

Sari, R. (2015). Pengaruh Frekuensi Penyiraman dan Dosis Pupuk Kandang Ayam terhadap Pertumbuhan dan Hasil Tanaman Pakchoy (Brassica rapa L. var. chinensis) (Doctoral dissertation, Universitas Brawijaya).

Sitompul, H. F., Simanungkalit, T., \& Mawarni, L. L. (2014). Respons pertumbuhan bibit kakao (Theobroma cacao L.) terhadap pemberianpupuk kandang kelinci dan pupuk NPK (16: 16: 16). Jurnal Agroekoteknologi Universitas Sumatera Utara, 2(3), 1064-1071. doi:10.32734/jaet.v2i3.7462

Syafruddin, S., Nurhayati, N., dan Wati, R. (2012). Pengaruh jenis pupuk terhadap pertumbuhan dan hasil beberapa varietas jagung manis. Jurnal Floratek, 7(1), 107-114.

Triastuti, F., Wardati, W., \& Yulia, A. E. (2016) Pengaruh pupuk kascing dan pupuk NPK terhadap pertumbuhan bibit tanaman kakao (Theobroma cacao L.). Jurnal Online Mahasiswa Fakultas Pertanian Universitas Riau, 3(1), 1-13.

Ulfa, N. K. (2018). Pengaruh Pemberian Pupuk Kascing terhadap Pertumbuhan Tanaman Kelapa Sawit (Elaeis guineensis Jacq.) di Main Nursery (Doctoral Dissertation, Universitas Andalas).

Yusuf, H., Sahputra, R., \& Irfansyah, R. (2019). Pengaruh media tanam dan pemberian pupuk organik cair terhadap pertumbuhan bibit kakao (Theobroma cacao L.). BIOnatural: Jurnal Ilmiah Pendidikan Biologi, 5(1), 1-11. 